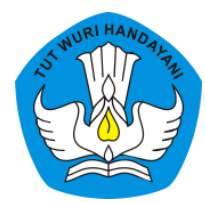

Page: 151-168

\title{
Komik Timbul Cerdisbusi Berbantuan Kelas Maya untuk Meningkatkan Hasil Belajar Siswa Sekolah Dasar
}

\author{
Ayu Chandra Astari \\ Sekolah Dasar Negeri Oro-Oro Ombo 02, Kota Batu \\ ${ }^{1}$ Contributor Email: ayuchandraastari@gmail.com
}

\begin{abstract}
Published: Mar 30, 2020
Article Url: http:/ / ojsdikdas.kemdikbud.go.id/index.php/didaktika/article/view/158

Abstract

The aim of the research is to overcome the problems that happen in 6th graders of SDN Oro-Oro Ombo 02 in theme 2 for KD IPS and Bahasa Indonesia. Students should understand the material and present the report in written, oral and visual forms. Teacher used Komik Timbul CerDisBuSi Berbantuan Kelas Maya to overcome the problems. This Classroom Action Research done in 2 cycles with 2 meetings each. From the cycle II reflection, there are 30 students $(94 \%)$ reached the KKM in understanding the material with the average score 86,67. There are 29 students (90\%) that can deliver their report presentation briliantly with the average score 85,00. Each aspect in Cycle II has increased from Cycle I therefore it can be concluded that Komik Timbul CerDisBuSi Berbantuan Kelas Maya can increase students' understanding and skills in presenting report.
\end{abstract}

Keywords: Komik Timbul; Virtual Class, Presenting Report Skill, Elementary School 


\begin{abstract}
Abstrak
Tujuan penelitian adalah untuk menyelesaikan permasalahan komik timbul cerdisbusi yang terjadi pada pembelajaran kelas VI SDN Oro-Oro Ombo 02 Batu pada pembelajaran Tema 2 pada KD muatan IPS dan Bahasa Indonesia. KD tersebut menuntut siswa untuk dapat memahami materi dan menyajikan laporan secara visual, tulis dan lisan. Guru memperbaiki pembelajarannya menggunakan Komik Timbul CerDisBuSi Berbantuan Kelas Maya. Metodepenelitian yang digunakan adalah Penelitian Tindakan Kelas (PTK) dengan 2 siklus yang tiap siklusnya terdiri dari dua pertemuan. Dari hasil refleksi pada siklus II, siswa yang memenuhi KKM sebanyak 30 siswa (94\%) siswa dalam aspek pemahaman terhadap materi dengan rata-rata nilai 86,67 dan sebanyak 29 siswa (90\%) dalam aspek keterampilan menyajikan laporan dengan rata-rata nilai 85,00. Tiap aspek yang dinilai di siklus 2 meningkat dari hasil siklus I. Dapat disimpulkan bahwa Komik Timbul CerDisBuSi Berbantuan Kelas Maya dapat meningkatkan hasil belajar siswa sekolah dasar.
\end{abstract}

Kata Kunci: Komik Timbul; Kelas Maya; Keterampilan Menyajikan Laporan; Sekolah Dasar

\title{
A. Pendahuluan
}

Siswa Sekolah Dasar adalah generasi penerus bangsa yang akan menghadapi ketatnya persaingan. Mereka terlahir pada dunia yang serba praktis, serba cepat dimana segala informasi yang mereka butuhkan didapatkan dengan cara yang sangat mudah. Kemajuan teknologi tidak dapat dihindari dalam kehidupan sehari-hari pun dalam pembelajaran Sekolah Dasar (SD). Siswa SD saat ini harus dibekali kemampuanuntuk dapat menyaring dan menganalisa berbagai informasi yang ada di sekitar mereka dan mengambil keputusan yang tepat berdasarkan hasil analisa yang mereka lakukan. Siswa saat ini bukan lagi hanya sebagai penerima informasi namun ia harus bisa mengolah dan menyajikan informasi dengan baik. Kegiatan belajar mengajar tentunya harus bisa mengakomodir hal ini. Untuk membuat siswa belajar, diperlukan adanya pembelajaran yang efektif, menarik dan juga menantang bagi siswa. Naim 
(2009:175) berpendapat semangat siswa dalam belajar dapat dibangkitkan dengan menciptakan pembelajaran sedemikian rupa sehingga berjalan dalam suasana yang menyenangkan.

Hasil belajar adalah perubahan keterampilan dan kecakapan, kebiasaan sikap, pengertian, pengetahuan, dan apresiasi, yang dikenal dengan istilah kognitif afektif, dan psikomotor melalui perbuatan belajar (Abror, 1993:65). Hasil Belajar dalam penelitian ini difokuskan kepada pemahaman konsep dan keterampilan menyajikan laporan secara tulis, lisan dan visual.

Keterampilan menyajikan atau mempresentasikan laporan secara visual, tulis dan lisan tentunya adalah keterampilan yang harus dimiliki oleh siswa. Hal tersebut termasuk dalam keterampilan abad 21 yakni keterampilan komunikasi. Selain itu, kemampuan mengomunikasikan juga termasuk dalam pendekatan saintifik atau 5M (Mengamati, Menanya, Mencoba, Menalar, dan Mengomunikasikan) yang telah identik diusung pembelajaran tematik terpadu pada Kurikulum 2013. Kondisi pembelajaran yang diharapkan dari pendekatan saintik adalah mendorong peserta didik dalam mencari tahu dari berbagai sumber melalui observasi, bukan hanya diberi tahu (Umi,2015:28). Keterampilan menyajikan laporan juga melatih siswa untuk bertanggungjawab terhadap keputusan yang diambil, mempertahankan pendapat dengan pemikiran yang matang, melatih keterampilan berbicara di depan umum, menyampaikan ide/gagasan dan juga melatih kepercayaan diri siswa yang sangat diperlukan bagi kehidupan mereka sehari-hari. Tentunya sebelum bisa mengomunikasikan ide atau pendapatnya, dibutuhkan pemahaman yang mendalam terhadap suatu materi. 
Kondisi di lapangan ternyata cukup berbeda dari yang diharapkan. Pada materi Tema 2 kelas VI di SDN Oro-Oro Ombo 02 Batu terdapat beberapa KD yang cukup sulit untuk dicapai oleh siswa. KD tersebut adalah KD muatan Bahasa Indonesia dan muatan IPS yang menuntut siswa untuk dapat memaparkan informasi dan menyajikan laporan tentang kejadian sejarah secara lisan, tulis dan visual. Pada Buku Siswa Kelas VI Tema 2 terdapat beberapa kegiatan penunjang yakni membaca informasi tentang kejadian sejarah, berdiskusi tentang kejadian sejarah bersama kelompoknya, menggali informasi dari teks melalui peta pikiran dan menyajikan laporan di depan kelas.

Materi kejadian sejarah yang cukup banyak jenisnya dalam satu subtema membuat siswa cukup kesulitan dalam memahami seluruh kejadian sejarah tersebut secara penuh dan runtut. Peta pikiran yang dibuat rupanya tidak cukup membantu siswa dalam memaparkan dan menyajikan informasi dengan lancar. Selain itu, siswa merasa tidak percaya diri dalam menyajikan laporannya di depan kelas karena kurang memahami materi dengan baik. Akibatnya, siswa menjadi kurang antusias dan bersikap pasif terhadap pembelajaran dan tidak memperhatikan siswa yang sedang menyajikan laporan. Hal ini tentunya cukup mengganggu jalannya pembelajaran karena materi tidak tersampaikan dan tidak dapat dipahami dengan baik oleh siswa.

Hal ini tercermin dari hasil penilaian beberapa aspek dalam pembelajaran sebelumnya. Untuk tingkat pemahaman siswa terhadap materi, hanya 10 siswa (32\%) yang mencapai KKM sedangkan sebanyak 22 siswa (68\%) siswa tidak mencapai KKM sekolah yakni 65. Keterampilan siswa dalam menyajikan laporan juga sangat kurang. Hanya sebanyak 8 siswa (25\%) siswa berhasil mencapai KKM dan 
sebanyak 24 siswa (75\%) tidak berhasil mencapai KKM. Keaktifan siswa juga belum terlihat dikarenakan banyak siswa yang masih belum maksimal dalam bekerja bersama kelompoknya. Siswa tidak memperhatikan penjelasan kelompok lain dan bersikap pasif saat pembelajaran.

Berdasarkan pengalaman dan pengamatan tersebut, timbul keinginan guru memperbaiki pembelajarannya untuk membantu siswa lebih lancar berkomunikasi dalam menyajikan atau memaparkan informasi secara tulis, visual dan lisan dengan merancang pembelajaran yang menarik dan dapat mengeksplorasi kemampuan siswa untuk memahami materi secara menyeluruh namun tetap menyenangkan bagi siswa. Selain itu, guru juga harus mampu merancang pembelajaran yang cukup menantang bagi siswa sehingga mereka lebih termotivasi untuk memahami materi kejadian sejarah lebih dalam dan mau berlatih menyajikan laporan dengan baik.

Solusi yang ditawarkan adalah dengan menggunakan Komik Timbul CerDisBuSi Berbantuan Kelas Maya. Menurut Maharsi (2011:10), komik mempunyai peranan yang besar untuk memberikan informasi yang mendidik, menghibur, sekaligus mempengaruhi seperti hakekat fungsi dari komunikasi. Komik Timbul adalah penggabungan dari buku komik dan juga kartu Pop-Up. Hal ini merupakan hal baru yang menarik bagi siswa. Komik kebanyakan berbentuk buku dengan ukuran yang cukup kecil dan aktivitas yang ditawarkan hanya sebatas aktivitas membaca saja. Komik Timbul adalah komik modifikasi yang bisa membantu siswa untuk memahami materi dan berlatih menyajikan materi secara lisan, tulis dan visual dengan cara yang menarik dan menantang. 
CerDisBuSi adalah singkatan dari Cermati-Diskusikan-BuatSajikan yang merupakan langkah-langkah pembelajaran yang telah dirancang guru dengan menggunakan komik timbul. Pada tahap Cermati, siswa mencermati Komik Timbul. Guru memperkenalkan Komik Timbul CerDisBuSi kepada siswa dan memperbolehkan mereka mencoba menggunakan Komik Timbul CerDisBuSi. Guru juga mendemonstrasikan cara menyajikan laporan secara lisan yang baik kepada siswa. Siswa mencermati penjelasan guru tentang cara pembuatan Komik Timbul CerDisBuSi. Hal kedua yang harus dilakukan pada tahapan ini adalah siswa mencermati teks kejadian sejarah yang diberikan oleh guru dan memahami isinya.

Pada tahap Diskusikan, siswa mulai membentuk kelompok dan berdiskusi tentang teks kejadian sejarah dan merancang pembuatan produk Komik Timbul CerDisBuSi. Siswa dituntut untuk berpikir kritis tentang rangkaian kejadian penting dalam teks yang perlu divisualisasikan supaya menjadi satu buku komik yang utuh. Perancangan ini merupakan bagian yang penting dalam langkah dan guru membimbing siswa untuk dapat memahami materi secara utuh dan membuat konsep rancangan yang matang.

Pada tahap Buatlah, siswa diminta untuk membuat Komik Timbul CerDisBuSi bersama kelompoknya sesuai dengan rancangan yang telah mereka buat pada tahap Diskusikan. Semua anggota kelompok diharuskan berperan aktif dalam kelompoknya dan guru mulai mengevaluasi keaktifan dan tetap membimbing siswa.

Tahap sajikan adalah tahap penting dalam penerapan Media Komik Timbul CerDisBuSi. Untuk menantang siswa meningkatkan kemampuan TIK-nya, pada tahap ini siswa diminta membuat video 
presentasi dengan menggunakan Komik Timbul CerDisBuSi. Selanjutnya, siswa mengunggah video tersebut ke dalam Kelas Maya Google Classroom yang telah dibuatkan guru. Diharapkan siswa dapat saling mengapresiasi karya orang lain dan belajar dari hasil video rekaman kelompok lain.

Rumusan masalah dalam penelitian ini yakni: (a) bagaimanakah Komik Timbul CerDisBuSi Berbantuan Kelas Maya dapat meningkatkan kemampuan siswa dalam memahami materi kejadian sejarah?, (b) bagaimanakah Komik Timbul CerDisBuSi Berbantuan Kelas Maya dapat meningkatkan keterampilan siswa dalam menyajikan laporan?

Berdasarkan rumusan masalah tersebut, tujuan dari penelitian ini adalah untuk: (1) meningkatkan kemampuan siswa dalam memahami materi kejadian sejarah, (2) meningkatkan keterampilan siswa dalam menyajikan laporan.

Komik Timbul CerDisBuSi Berbantuan Kelas Maya memiliki beberapa manfaat: (1) meningkatkan keaktifan siswa dalam pembelajaran, (2) meningkatkan kemampuan siswa dalam memahami materi kejadian sejarah, (3) meningkatkan keterampilan siswa dalam membuat produk berupa komik timbul, (4) meningkatkan kemampuan TIK siswa, dan (5) dapat meningkatkan keterampilan siswa dalam menyajikan laporan secara lisan, tertulis dan visual.

\section{B. Metode}

Desain penelitian ini menggunakan Penelitian Tindakan Kelas (PTK) model Kemmis McTaggart.Subyek penelitian ini adalah 32 siswa (18 laki-laki dan 14 perempuan) kelas VI SDN Oro-Oro Ombo 02 Kota Batu Jawa Timur. Waktu penelitian dilaksanakan mulai 18 Agustus sampai 30 September 2019 dengan materi Upaya Mempertahankan 
Kemerdekaan Indonesia. Penelitian dilaksanakan dalam 2 siklus yang tiap siklusnya terdiri dari 2 pertemuan. Tiap siklus dalam PTK terdapat 4 tahapan yakni Perencanaan, Pelaksanaan, pengamatan dan refleksi.

Instrumen penelitian yang digunakan tetap mengacu pada tiga rahan yakni kognitif, afektif dan psikomotor. Tes tulis digunakan untuk mengetahui pencapaian kognitif siswa dalam hal pemahaman konsep. Ranah afektif dipantau dengan menggunakan lembar observasi untuk mengetahui tingkat keaktifan siswa. Pada ranah psikomotor, digunakan lembar observasi disertai rubrik untuk mengetahui tingkat keberhasilan siswa dalam keterampilan menyajikan laporan baik secara lisan, tulis dan visual. Data hasil tes tulis dianalisis secara deskriptif kuantitatif dan hasil observasi siswa dianalis secara deskriptif kualitatif. Hasil analisis data digunakan pada tahap refleksi untuk perbaikan pembelajaran pada siklus berikutnya. Secara ringkas, metode penelitian dapat dilihat pada bagan alir berikut ini.

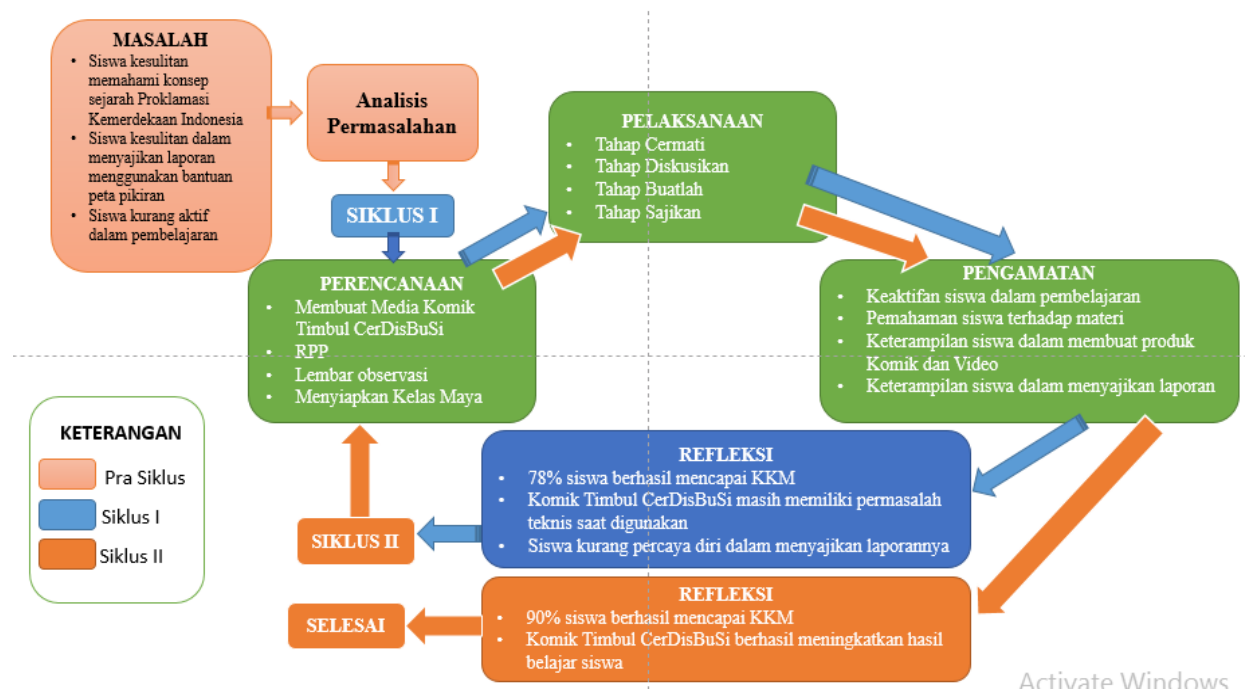

Gambar : Bagan Alir Penelitian 


\section{Hasil dan Pembahasan}

Hasil belajar yang akan diukur pada pembelajaran tematik menggunakan Komik Timbul CerDisBuSi ini adalah hasil tes siswa untuk ranah pengetahuan dan juga hasil unjuk kerja menyajikan laporan dalam bentuk video yang telah diunggah ke Kelas Maya.

Tabel 1 Rekap Skor Hasil Tes Tulis Pemahaman Konsep Siswa

\begin{tabular}{lccc}
\hline \multicolumn{1}{c}{ Siklus } & $\begin{array}{c}\text { Rata-Rata } \\
\text { Skor Siswa }\end{array}$ & $\begin{array}{c}\text { Siswa } \\
\text { Tuntas }\end{array}$ & $\begin{array}{c}\text { Siswa Tidak } \\
\text { Tuntas }\end{array}$ \\
\hline Siklus I & 76.25 & 26 & 6 \\
\hline Siklus II & 86.67 & 30 & 2 \\
\hline
\end{tabular}

Pemahaman siswa terhadap materi kejadian sejarah setelah siswa membuat Komik Timbul CerDisBuSi menjadi meningkat. Pada siklus I tingkat pemahaman siswa terhadap materi mencapai 76,25 persen. Pada siklus II terjadi peningkatan dalam pemahaman siswa terhadap materi yakni mencapai 86,67 persen. Hasil ini didapatkan dari nilai rata-rata tes yang diberikan pada peserta pada setiap siklusnya.

Peningkatan pemahaman ini dikarenakan siswa terlibat secara afektif, kognitif dan psikomotor. Pada Tahap Diskusikan siswa diminta untuk mendiskusikan gambar-gambar yang dapat mewakili teks narasi yang diberikan oleh guru. Dengan mereka memikirkan dan mendiskusikan hal ini, sebenarnya keterampilan berpikir kritis mereka tengah diuji. Dari sekian banyak kejadian dalam teks, mereka harus memilih hanya 5 gambar saja yang bisa menjelaskan keseluruhan rangkaian kejadian. Mau tidak mau, siswa harus memahami secara mendalam runtutan kejadian yang akan mereka ekspresikan ke dalam gambar-gambar Komik Timbul CerDisBuSi.

Tidak jarang mereka terlihat saling adu argumen dan mempertahankan pendapatnya. Hal ini merupakan hal yang baik dan positif karena siswa seyogyanya ingin memberikan yang terbaik pada kelompoknya. Peran guru dalam hal ini adalah sebagai penengah dan 
juga pembimbing siswa apabila mereka merasa kesulitan dalam tahap Diskusikan. Guru memberikan beberapa alternatif pilihan dan membuat siswa memilih yang sesuai dengan hati nuraninya.

Selain itu, pemahaman siswa terhadap konsep juga didapatkan pada proses saat siswa berlatih menggunakan Komik Timbul CerDisBuSi. Rekaman video yang dilakukan oleh kelompok membuat siswa harus memahami kejadian sejarahnya secara menyeluruh. Siswa saling belajar dan bekerjasama dalam proyek pembuatan video supaya jalan cerita yang tergambar dalam Komik Timbul CerDisBuSi sesuai dengan runtutuan kejadian sejarah yang benar. Hal ini tentunya akan sangat membantu siswa dalam memahami konsep materi dengan benar namun menyenangkan.

Tidak berhenti di situ saja, hasil Komik Timbul CerDisBuSi digunakan dan diletakkan di ruang kelas sehingga siswa lain pun dapat membaca dan memahami Komik Timbul CerDisBuSi dari kelompok lain. Sehingga pengayaan siswa setelah pembelajaran dapat dilakukan karena ada produk representatif yang dihasilkan dari siswa. Siswa dapat memilih materi mana yang belum dimengertinya dan berlatih menyajikan laporan secara mandiri sekaligus memperkuat pemahaman konsepnya.

Kelas Maya dalam hal ini juga dimaksudkan oleh guru sebagai bahan pengayaan. Siswa diberikan pengetahuan dan alternatif untuk melihat hasil karya kelompok lain sekaligus memahami materi yang disampaikan oleh kelompok lain secara berulang-ulang. Hal tersebut tentunya tidak dapat dilakukan dengan cara yang konvensional saat kelompok menyajikan laporannya di depan kelas. Selain itu, siswa dapat berkomunikasi melalui kelas maya namun karena keterbatasan akses internet yang dialami oleh siswa, hal ini belum terlaksana secara kontinyu. Hal tersebut tidaklah menjadi masalah yang krusial karena tujuan utama guru membuat Kelas Maya ini adalah sebagai media penyimpanan video berbasis dunia maya yang dapat diakses siswa 
dimana saja dan kapan saja untuk memperkuat pemahaman konsep siswa terhadap materi.

Dalam memahami materi, diperlukan banyak variasi agar dapat mengakomodasi gaya kognitif dari banyak siswa. Siswa tentunya memiliki gaya dan teknik tersendiri dalam memahami suatu materi atau konsep. Hal ini dijelaskan oleh Ampuni ( 2015) yang menyatakan bahwa gaya kognitif siswa adalah kebiasaan-kebiasaan pemrosesan; informasi, pola pikir yang biasa dipakai individu dalam belajar. Contohnya adalah gaya reflektif dan gaya impulsif. Gaya reflektif siswa identik dengan pengumpulan bukti-bukti pendukung sebelum membuat suatu kesimpulan. Berbeda dari gaya reflektif, gaya impulsif cenderung mengambil keputusan dengan cepat tanpa memperhatikan fakta-fakta yang ada. Dengan berbagai macam teknik dan alternatif cara yang diberikan kepada siswa dalam pemahaman materi atau konsep, diharapkan siswa lebih termotivasi dalam pembelajaran.

Tabel 2 Rekap Hasil Penilaian Keterampilan Menyajikan Laporan

NO

ASPEK PENGAMATAN

SIKLUS I SIKLUS II

\begin{tabular}{llll}
\hline $\mathbf{1}$ & Pelafalan & $\mathbf{7 8 , 1 3}$ & 83,75 \\
\hline $\mathbf{2}$ & Intonasi & 75,63 & 82,50 \\
\hline $\mathbf{3}$ & Percaya diri & 86,25 & 88,75 \\
\hline & RATA-RATA & $\mathbf{8 0 , 0 0}$ & $\mathbf{8 5 , 0 0}$
\end{tabular}

Penilaian selanjutnya didapatkan dari hasil penilaian keterampilan dalam menyajikan laporan dalam bentuk video yang telah diunggah ke dalam Google Classroom yang bisa dilihat pada Tabel 2. Hal ini sangat berbeda dari yang dialami guru sebelumnya saat siswa menyajikan laporannya dalam bentuk peta pikiran. Mereka terlihat bingung dalam menyampaikan laporannya karena bentuk peta pikiran tersebut hanya selembar kertas yang berisikan peta pikiran saja. Hal tersebut dirasakan kurang mengasah kreativitas siswa dalam menyajikan laporan karena 
siswa hanya terpaku pada peta pikiran mereka saja sehingga proses pemahaman akan berubah menjadi proses penghafalan.

Hal ini terlihat berbeda pada saat mereka menggunakan media Komik Timbul CerDisBuSi Berbantuan Kelas Maya ini. Mereka dapat berlatih berulang-ulang untuk bercerita tentang kejadian sejarah bagiannya. Penggunaan gambar yang lebih banyak daripada tulisan akan merangsang kreativitas siswa dalam bercerita dengan menggunakan bahasa mereka sendiri, tidak terpaku pada tulisan yang ada pada komik. Hal ini tentunya akan sangat membantu dan mengarahkan siswa untuk menyajikan laporannya dengan sistematis namun juga menyenangkan bagi siswa.

Terlebih lagi, mereka juga dituntut untuk merekam aksi mereka dalam menyajikan laporan dalam bentuk rekaman video dan mengunggahnya pada kelas maya. Hal itu akan melatih kepercayaan diri mereka untuk tampil menyajikan laporannya di depan kamera. Ternyata pada saat implementasi pembelajaran, berperan di depan kamera dan menyajikan laporan secara langsung di depan kelas sama-sama memiliki tantangan untuk meningkatkan kepercayaan diri mereka dalam berkomunikasi dengan orang lain. Kelebihan dari menyajikan laporan lewat video pembelajaran yang diunggah dalam Kelas Maya yaitu memudahkan siswa untuk mengatur waktu sesuai dengan kondisi kelompok masing-masing. Pembelajaran tidak lagi hanya bisa dilakukan di ruang kelas dan pada jam sekolah saja. Ada kelompok yang merekam videonya pada sore hari di rumah, di kebun, di lapangan dan lain-lain. Hal ini tentunya akan sangat efektif dan menghemat waktu di tengah banyaknya tuntutan kurikulum. Hal ini sejalan dengan tujuan dari kelas maya yang disampaikan oleh Manarul (2019) yaitu: 1) menciptakan pembelajaran yang bisa berlangsung kapan saja dan dimana saja dengan menghemat waktu dan biaya; 2) meningkatkan keterampilan penggunaan teknologi IT siswa sehingga siswa lebih kreatif, sekaligus bisa menambah minat siswa untuk belajar, dan 3) lebih memaksimalkan 
kemampuan pribadi masing-masing walaupun diluar kelas tatap muka/kelas langsung.

Mengunggah video mereka dalam kelas maya tentunya juga menjadi tantangan tersendiri bagi mereka untuk dapat menyajikan laporan mereka sebaik-baiknya. Selain itu, mereka dilatih untuk dapat mengomunikasikan pendapatnya kepada orang lain (orang tua maupun pihak ahli) agar dapat menyelesaikan tugas yang diberikan. Menggabunggabungkan video tentu bukanlah hal yang mudah tapi bukan tidak mungkin untuk dilakukan. Ada siswa yang bersemangat sekali bertanya tentang program penggabungan video namun ada juga yang meminta ahli untuk membuatnya. Dari sinilah guru bisa melihat dan mencermati minat dan bakat siswa.

Ada 2 produk yang turut dinilai dalam implementasi pembelajaran ini yaitu produk Komik Timbul dan produk Video pembelajaran. Siswa ternyata di luar ekspektasi dapat menghasilkan gambar dan karya buku Komik Timbul CerDisBuSi dan video pembelajaran dengan bagus dan original. Karya Komik Timbul CerDisBuSi buatan mereka disimpan di dalam kelas dan dapat digunakan siswa lain saat istirahat untuk bisa dibaca dan berlatih dalam menyajikan laporannya.

Siswa sebenarnya memiliki potensi yang luar biasa yang tidak disadarinya. Gurulah yang harus menemukan itu dan menggiring mereka untuk bereksplorasi mengerahkan potensi tersebut secara maksimal. Hal ini sejalan dengan Kemdikbud (2008:8) yang menyatakan bahwa peranan guru meliputi banyak hal, yaitu guru dapat berperan sebagai pengajar, pemimpin kelas, pembimbing, pengatur lingkungan belajar, perencana pembelajaran, supervisor, motivator, dan sebagai evaluator. Dengan membuat produk Komik Timbul CerDisBuSi ini, guru dapat mengidentifikasi dan melihat potensi, minat dan bakat siswa untuk menjadi dasar bagi guru dalam mengarahkan siswa belajar.

Kemampuan siswa dalam penerapan IT ini juga berbeda namun itu tidak menghalangi guru untuk mengarahkan mereka sesuai 
kemampuannya. Perkembangan teknologi dalam kehidupan mereka tidak mungkin dihindari. Oleh karena itu siswa SD pun harus dibekali untuk dapat menggunakan teknologi sebagai kawan mereka bukan musuh yang membawa dampak negatif. Ketika siswa kita lulus dan menghadapi dunia yang sebenarnya, mereka akan hidup dengan kepungan teknologi yang semakin berkembang. Hal ini sesuai dengan pernyataan Scott (2015, dalam Zubaidah, 2016:2) menambahkan bahwa teknologi informasi dan komunikasi telah mengubah cara kita belajar, sifat pekerjaan yang dapat dilakukan, dan makna hubungan sosial. Pengambilan keputusan bersama, berbagi informasi, berkolaborasi, berinovasi, dan kecepatan bekerja menjadi aspek yang sangat penting pada saat ini.

Media Komik Timbul CerDisBuSi Berbantuan Kelas Maya ini dikatakan berhasil penggunaannya dalam pembelajaran tematik Tema 2 di kelas 6 SDN Oro-oro Ombo 02 Kota Batu. Hal ini tampak dalam meningkatnya keaktifan dan keterampilan siswa dalam proses pembelajaran dan produk yang mereka hasilkan mulai dari Siklus I dan Siklus II. Seperti yang terlihat pada diagram di bawah ini.

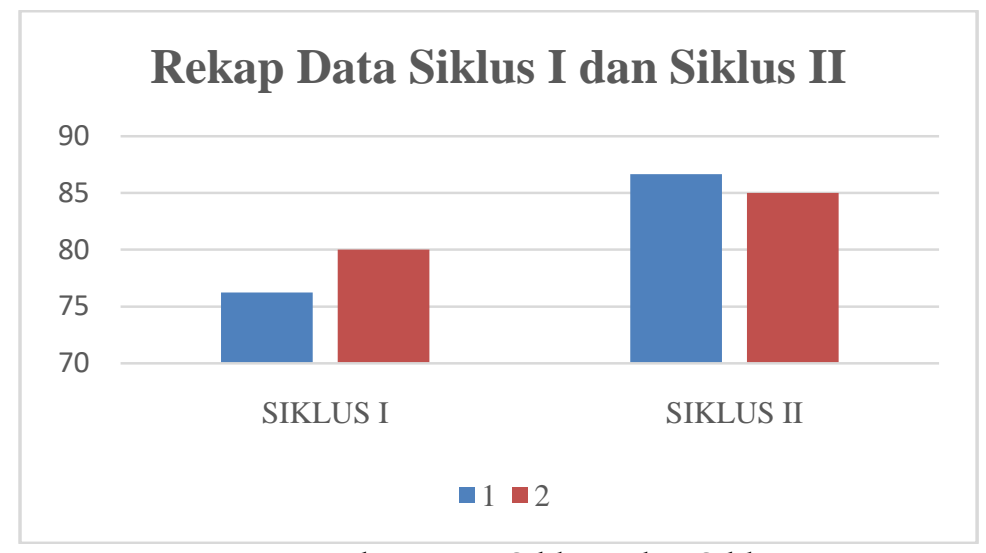

Diagram Rekap Data Siklus I dan Siklus II

Tantangan yang diberikan pada siswa ternyata juga bisa menambah semangat, keaktifan dan motivasi mereka dalam belajar. Hal ini sejalan dengan pendapat Naim (2009:175) yang berpendapat bahwa untuk membuat siswa belajar, diperlukan adanya pembelajaran yang 
efektif, menarik dan juga menantang bagi siswa. Semangat siswa dalam belajar dapat dibangkitkan dengan menciptakan pembelajaran sedemikian rupa sehingga berjalan dalam suasana yang menyenangkan.

Media Komik Timbul CerDisBuSi Berbantuan Kelas Maya terbukti telah membuat siswa menjadi lebih aktif dan berperan dalam pembelajaran. Peran siswa bukan hanya sebagai penerima informasi namun juga berperan sebagai penemu pengetahuan yang aktif dengan cara membangun pengetahuannya sendiri. Keaktifan mereka dalam berproses menunjukkan bahwa mereka tidak hanya terlibat secara fisik saja namun juga ada aktivitas mental disitu yang mendasari mereka belajar secara sadar. Hal ini sejalan dengan pendapat Pane \& Dasopang (2017:335) yang mengatakan bahwa kegiatan belajar dikatakan baik apabila intensitas keaktifan jasmani maupun mental seseorang semakin tinggi. Semakin tinggi aktivitas mental dan jasmani yang terlibat maka kegiatan belajar dapat dikatakan baik dan berhasil.

Media Komik Timbul CerDisBuSi Berbantuan Kelas Maya ini juga bisa menjawab tantangan pembelajaran Abad 21. Aspek 4K yang terdiri dari berpikir kritis, kreatif, komunikasi dan kolaborasi adalah modal bagi siswa untuk bekerja di masa depan. Hal ini sejalan dengan dengan pernyataan Scott (2015 dalam Zubaidah, 2016:2) yang mengatakan bahwa pekerjaan di abad 21 bersifat lebih internasional, multikultural dan saling berhubungan. Aspek keterampilan abad 21 yang diimplementasikan dalam pembelajaran ini dijabarkan sebagai berikut.

\section{Aspek Berpikir Kritis}

Kemampuan berpikir kritis siswa dilatih saat siswa harus membaca teks tentang upaya mempertahankan kemerdekaan Indonesia dan mengintepretasikankan pemahamannya melalui gambar. Menggambarkan situasi dalam teks melalui gambar membutuhkan kemampuan berpikir kritis yang masih sesuai dengan karakteristik siswa. 
Siswa harus memilah bagian mana dari teks yang penting dan harus disampaikan melalui gambar dan mana yang tidak. Selain itu, siswa juga harus memikirkan keterkaitan alur melalui gambar.

\section{Aspek Kreatif}

Kreatifitas siswa sangat terlihat pada kegiatan pembelajaran merancang dan membuat Komik Timbul CerDisBuSi. Untuk menghasilkan Komik Timbul ini, peserta harus kreatif dalam memodifikasi barang-barang sederhana yang ada di sekitar mereka menjadi sebuah karya yang membantu mereka dalam memahami materi pembelajaran. Selain itu, kreativitas mereka juga dituntut saat mereka harus merekam video rekaman menggunakan Komik Timbul CerDisBuSi milik mereka.

\section{Aspek Komunikasi}

Bagian pembelajaran yang mengimplementasikan aspek komunikasi yaitu saat presentasi atau menyajikan laporan tentang kejadian sejarah Upaya Mempertahankan Kemerdekaan Indonesia dengan media Komik Timbul CerDisBuSi kepada kelompok lain melalui video rekaman mereka yang diunggah melalui Kelas Maya. Siswa merasa terbantu dengan media Komik Timbul CerDisBuSi karena dapat digunakan kapan saja dan mudah dibawa kemana-mana untuk digunakan dalam berlatih mengomunikasikan hasil karyanya. Selain itu, penggunaan video rekaman yang diunggah dalam kelas maya turut membantu menjadi lebih literat teknologi dalam era revolusi industri 4.0.

\section{Aspek Kolaborasi}

Pembelajaran menggunakan media Komik Timbul CerDisBuSi Berbantuan Kelas Maya ini merupakan suatu proyek yang harus dikerjakan dengan kelompoknya. Siswa harus berkolaborasi dengan kelompoknya untuk menghasilkan karya yang akan disajikan. Kolaborasi terlihat saat siswa berbagi tugas, memberi masukan kepada teman 
sekelompok, bernegoisasi tentang ide siapa yang akan dipakai dalam karya sehingga tercipta sebuah karya yang bisa mereka banggakan.

Komik Timbul CerDisBuSi juga menggunakan bantuan Kelas Maya yang dapat melatih literasi digital siswa yang mereka perlukan untuk menghadapi era revolusi industri 4.0. Tidak bisa dipungkiri bahwa teknologi akan menjadi bagian vital dalam kehidupan kita di masa mendatang pada segala bidang. Siswa harus bisa menguasai teknologi untuk mereka gunakan dalam kehidupan mereka sehari-hari. Pembelajaran di sekolah tentunya juga harus memanfaatkan teknologi sesuai dengan karakteristik materi yang diajarkan. Komik Timbul CerDisBuSi Berbantuan Kelas Maya dapat digunakan untuk melatih siswa sebagai bentuk persiapan menghadapi era revolusi industri 4.0.

\section{Penutup}

Berdasarkan dari penerapan media Komik Timbul CerDisBuSi Berbantuan Kelas Maya ini dapat ditarik beberapa kesimpulan sebagai berikut.

1. Media pembelajaran Komik Timbul CerDisBuSi Berbantuan Kelas Maya dapat meningkatkan pemahaman konsep siswa. Hal ini dibuktikan pada langkah Cermati yakni pemetaan konsep peta pikiran dari materi yang dibagikan guru yang dituliskan siswa sebelum mereka membuat produk Komik Timbul CerDisBuSi. Analisis jawaban mereka menunjukkan bahwa mereka memahami materi melalui beberapa aspek (apa, siapa, dimana, kapan, mengapa, bagaimana) yang tercantum dalam KD.

2. Media pembelajaran Komik Timbul CerDiBuSi Berbantuan Kelas Maya dapat meningkatkan keterampilan siswa dalam menyajikan laporan. Laporan dibuat melalui produk Komik Timbul CerDisBuSi. Hal ini dikarenakan siswa memiliki pemahaman materi yang memadai dan alat bantu dalam menyajikan laporannya. 


\section{Ucapan Terima Kasih}

Ucapan terima kasih disampaikan kepada Bapak Budiyono, S.Pd. selaku kepala sekolah dan juga keluarga besar SDN Oro-Oro Ombo 02 Kota Batu atas dukungan baik moril dan materiil yang diberikan sehingga penelitian ini dapat diselesaikan dengan baik.

\section{Daftar Referensi}

Abror, A. R. 1993. Psikologi Pendidikan. Yogyakarta: Tiara Wacana.

Ampuni, S. 1998. Proses Kognitif dalam pemahaman bacaan. Buletin Psikologi, 6(2).

Kemendikbud. 2008. Penilaian kinerja guru. Jakarta: Departemen Pendidikan Nasional.

Maharsi, I., Pamungkas, E. A., \& Oemank. 2011. Komik: Dunia Kreatif Tanpa Batas. Yogyakarta : Kata Buku.

Manarul, A. 2019. Kelas Maya (Lengkap): Jenis, Tujuan, Manfaat, Contoh. (Tersedia di https://wwww.yuksinau.id/kelas-mayal, diakses tanggal 20 Mei 2019).

Naim, N. 2009. Menjadi Guru Inspiratif. Yogyakarta: Pustaka Pelajar

Pane, A., Dasopang, M.D. 2017. Belajar dan pembelajaran. Fitrah: Jurnal Kajian Ilmu-ilmu Keislaman, 3(2), pp.333-352.

Umi, U. 2015. Penerapan pendekatan saintifik melalui model project based learning untuk meningkatkan ketrampilan proses dan hasil belajar siswa kelas IV SD negeri seworan, Wonosegoro. Scholaria: Jurnal Pendidikan dan Kebudayaan, 5(1), 24-38.

Zubaidah, S. 2016. Keterampilan abad ke-21: Keterampilan yang diajarkan melalui pembelajaran. In Seminar Nasional Pendidikan dengan tema "Isu-isu Strategis Pembelajaran MIPA Abad (Vol. 21, No. 10). 